\title{
Using laser micro-dissection and qRT-PCR to analyze cell type-specific gene expression in Norway spruce phloem
}

The tangentially oriented polyphenolic parenchyma (PP) and radially organized ray parenchyma in the phloem are central in the defense of conifer stems against insects and pathogens. Laser microdissection enables examination of cell-specific defense responses. To examine induced defense responses in Norway spruce stems inoculated with the necrotrophic blue-stain fungus Ceratocystispolonica, RNA extracted from laser micro-dissected phloem parenchyma and vascular cambium was analyzed using real-time RT-PCR (qRT-PCR) to profile transcript levels of selected resistance marker genes. The monitored transcripts included three pathogenesis-related proteins (class IV chitinase (CHI4), defensin (SPI1), peroxidase ( $P X 3)$, two terpene synthesis related proteins (DXPS and $L A S$ ), one ethylene biosynthesis related protein (ACS), and a phenylalanine ammonia-lyase $(P A L)$. Three days following inoculation, four genes ( $C H I 4, P A L, P X 3, S P I 1)$ were differentially induced in individual cell and tissue types, both close to the inoculation site $(5 \mathrm{~mm}$ above) and, to a lesser degree, further away (10 $\mathrm{mm}$ above). These resistance marker genes were all highly induced in ray parenchyma, supporting the important role of the rays in spruce defense propagation. CHI4 and PAL were also induced in PP cells and in conducting secondary phloem tissues. Our data suggests that different cell types in the secondary phloem of Norway spruce have overlapping but not fully redundant roles in active host defense. Furthermore, the study demonstrates the usefulness of laser micro-dissection coupled with qRT-PCR to characterize gene expression in different cell types of conifer bark. 
1 Nina E. Nagy ${ }^{1}$, Katarzyna Sikora ${ }^{2}$, Paal Krokene ${ }^{1}$, Ari M. Hietala ${ }^{1}$, Halvor Solheim ${ }^{1}$, Carl

2 Gunnar Fossdal ${ }^{1}$

3

4

$5 \quad{ }^{1}$ Norwegian Forest and Landscape Institute, P. O. Box 115, NO-1431 Ås, Norway

6 2Forest Research Institute, Sękocin Stary, ul. Braci Leśnej 3, 05-090 Raszyn, Poland

9 Corresponding authors: Nina Elisabeth Nagy, nina.nagy@,skogoglandskap.no, Carl Gunnar

10 Fossdal, carl.fossdal@skogoglandskap.no

11 


\section{INTRODUCTION}

14 Norway spruce (Picea abies (L.) Karst.), a dominant species in Europe's boreal forests, is susceptible to the blue-stain fungus Ceratocystis polonica that is vectored into the stem by the spruce bark beetle Ips typographus L. During intermittent outbreaks, the beetle-fungus complex causes extensive tree mortality over large areas (Christiansen \& Bakke A, 1988; Wermelinger \& Seifert, 1999). Norway spruce has an array of constitutive and inducible defense responses against insect-fungus attacks, including well-characterized structural and biochemical defense in the stem phloem (Franceschi et al., 2000; 2005). Among the cell types thought to be pivotal in bark defense are polyphenolic parenchyma (PP) cells and radial ray cells, which make up the major proportion of living cells of the phloem. PP cells are organized in annual rings of axially oriented parenchyma cells that form almost continuous sheets around the phloem circumference (Franceschi et al., 1998; Krokene, Nagy \& Krekling, 2008). A characteristic feature of PP cells is the large vacuole that fills up most of the cell lumen and contains phenolic compounds (Franceschi et al., 1998). PP cells transport sugars to the surrounding parenchyma cells and store starch. The rays consist of parenchyma cells forming radial plates in the stem of conifers (Franceshi et al., 2005). Ray parenchyma store starch and form a living connection between the vascular cambium and the cork cambium, serving as a radial transport route for materials and signals in the bark.

Studies of the molecular basis of defense mechanisms in Norway spruce have shown upregulation of resistance marker genes coding for chalcone and stilbene synthase, as well as pathogenesis-related (PR) proteins such as chitinase, defensin and peroxidases in infected bark (Fossdal et al., 2003; 2007; 2012; Nagy et al., 2004). Furthermore, the ethylene biosynthesis related synthase ACS (ACC synthase) and the lignin related peroxidase PX3 are involved in defense against pathogenic fungi in Norway spruce bark (Koutaniemi et al., 2007; Yaqoob et al., 2012; Deflorio et al., 2011). Immuno-cytochemistry has indicated that both rays and PP cells take part in production of secondary metabolites, since they contain abundant phenylalanine ammonia lyase (PAL), a key enzyme in phenol synthesis (Franceschi et al., 1998; 2000).

Until recently, all studies of defense related gene expression in Norway spruce and other conifers had to be done at the whole-tissue level. However, specific cell types such as rays and PP cells may have specialized roles in e.g. pathogen recognition and systemic defense signaling, and analysing whole tissues with a mosaic of different cell types does not resolve such cell- or tissuespecific processes. Laser micro-dissection (LMD) allows isolation of individual cell and tissue 
45 types and has provided new insight into the role of specific phloem cells in conifer defense 46 responses (Li, Schneider \& Gershenzon, 2007; Li et al., 2012; Abbott et al., 2010; Luchi et al., 47 2012). Combining LMD and sensitive chemical analyses Li, Schneider \& Gershenzon (2007) showed that the lignified stone cells of Norway spruce bark also contain phenolic compounds, suggesting that these cells are involved in chemical as well as structural defense. More recently the same group showed that micro-dissected PP cells contain significantly higher concentrations of the stilbene glucoside astringin than neighboring sieve cells after infection with C. polonica (Li et al., 2012). LMD has also been used to characterize resin ducts and cambial tissue of white spruce phloem (Abbott et al., 2010) and to study expression of a constitutively expressed gene ( $\alpha$-tubulin) in micro-dissected Norway spruce phloem fragments consisting of multiple cell types (Luchi et al., 2012).

In this paper we use LMD to isolate ray and PP cells in Norway spruce phloem and analyze the differential gene expression of defense-related genes by quantitative Real Time RTPCR (qRT-PCR). This increases the resolution of defense-related gene expression analysis in Norway spruce down to individual cell types and is the first investigation of gene expression in the two most important cell types in conifer bark defenses. We hypothesize that ray and PP cells play central roles in defense signalling and synthesis of defense compounds.

\section{MATERIALS AND METHODS}

\section{Inoculation and tissue sampling}

Four 32-year-old ramets of a single Norway spruce clone (471), growing at the Hoxmark Experimental Farm of the Norwegian Forest and Landscape Institute in Ås, were used in this study. Clone 471 has strong, but not complete resistance to C. polonica infection, as determined by phloem lesion length following experimental inoculation (Nagy et al., 2005). It shows upregulation of the phenylpropanoid pathway in the phloem following both fungal infection and mechanical wounding (Koutaniemi et al., 2007).

Two ramets (A and B) of clone 471 were inoculated with C. polonica (isolate no. NISK $93-$ 208/115) on June 15, 2003, as described by Franceschi et al. (1998). Each ramet was inoculated at four sites in a circle around the stem between 1.5 and $2.0 \mathrm{~m}$ height. Tissue samples were collected 3, 7, 14 and 35 days after inoculation by removing a rectangular strip $(2 \times 10 \mathrm{~cm})$ of 
in the middle (Fig. 2A). At day 35, two control samples consisting of un-inoculated tissue was collected from ramet A at the same height, but $0.5 \mathrm{~m}$ away from the inoculation sites. All samples were frozen in liquid nitrogen immediately after harvesting and stored at $-80^{\circ} \mathrm{C}$.

\section{Cryo-sectioning}

For cryo-sectioning and subsequent LMD we only included control samples (ramet A) and inoculated samples collected 3 days after inoculation (ramet A and B). Prior to cryo-sectioning, phloem cubes $(5 \times 5 \times 5 \mathrm{~mm})$ were cut from inoculated bark samples 5 and $10 \mathrm{~mm}$ above the inoculation site and embedded and frozen in Optimal Cutting Temperature embedding medium (Sakura Finetek USA, Inc., USA). Similar-sized phloem cubes were cut from the control samples and processed in the same way.

Transversal cryo-sections ( $20 \mu \mathrm{m}$ thick) were cut from the upper part of each phloem cube using a cryo-microtome (Microm HM $560 \mathrm{MV}$, Microm International GmbH, Walldorf, Germany). Optimal sections were obtained at $-18^{\circ} \mathrm{C}$ for both specimen and knife. Ten sections, intended for LMD, were placed on nuclease and nucleic acid free PET-membrane frame slides (1.4 $\mu \mathrm{m}$, Leica MicroDissect GmbH, Herborn, Germany) and stored immediately in falcon tubes on dry ice. From each phloem cube we prepared two slides with five cross-sections per slide. The slides were stored at $-80^{\circ} \mathrm{C}$ for a few days prior to laser micro-dissection. Additional cryosections for morphological characterization were cut and processed as described below for tissue examined by light microscopy.

\section{Light microscopy}

Thin transversal-sections were cut from phloem cubes embedded in L. R. White resin (TAAB Laboratories, Aldermason, Berkshire, UK) for routine observations of morphology and presence of fungal hyphae. Samples were processed for light microscopy according to Nagy et al. (2000). Briefly, pieces were fixated (in 2\% paraformaldehyde and 1.25\% glutaraldehyde in $50 \mathrm{mmol} / \mathrm{L} \mathrm{L}$ piperazine-N-N'-bis (2-ethanesulfonic) acid buffer ( $\mathrm{pH}$ 7.2) for $12 \mathrm{~h}$ at room temperature), and dehydrated in an ethanol series (70-80-90-96-4 $\times 100 \%)$ before infiltration and polymerization (at $60^{\circ} \mathrm{C}$ for $24 \mathrm{~h}$ ) with L. R. White acrylic resin. Cross-sections (1.5 $\mu \mathrm{m}$ thick) were cut from all control samples and all inoculated samples collected 3-35 days after inoculation using an ultramicrotome for resin sections (Leica EM UC6, Leica Microsystems, Wetzlar, Germany). Both resin sections and the cryo-sections collected for morphological examination by light microscopy were dried onto superfrost ${ }^{\circledR P l u s ~ g l a s s ~ s l i d e s ~(M e n z e l-G l a ̈ z e r ®, ~ T h e r m o ~ S c i e n t i f i c, ~ G e r h a r d ~}$ 
110 Menzel GmbH, Braunschweig, Germany) and stained with Stevenel's blue (del Cerro, Cogen and 111 del Cerro, 1980).

\section{Laser micro-dissection (LMD)}

114 LMD was performed as described by Abbott et al. (2010), with adaption to the subjected cell and

115 tissue types. Cryo-sectioned phloem cross-sections were allowed to dry at room temperature for 5 116 minutes prior to micro-dissection with a LMD6000 Laser Micro-dissection Microscope (Leica

117 Microsystems CMS GmbH, Wetzlar, Germany). For optimal dissection we used laser energy

118 intensity between 85-100 and a cutting speed of 5. Different micro-dissected tissues were 119 collected individually into the cap of nuclease free $0.5 \mathrm{ml} \mathrm{PCR}$ tubes (Axygen, Union City, CA, 120 USA) containing $40 \mu$ of lysis buffer. The tubes were then closed and centrifuged at low speed 121 (3000 rpm) for 30 seconds to sediment the LMD samples, additional buffer was added to a final 122 volume of $60 \mu \mathrm{l}$, and the tubes were placed on dry ice.

123 Both individual cell types and specific tissue regions were micro-dissected from the 124 phloem cross-sections. Cell types selected for LMD at $20 \times$ magnification were PP cells and ray 125 parenchyma cells (RC), both occurring as clusters or rows of multiple cells in the secondary 126 phloem. In addition, un-differentiated cambium parenchyma cells were dissected at $6.3 \times$ 127 magnification. Tissue regions selected for LMD at $6.3 \times$ magnification were $(1)$ primary phloem 128 tissue near the periderm (old non-conducting phloem), (2) secondary phloem tissue $\sim 1000 \mu \mathrm{m}$ 129 centripetal to region (1) (non-conducting secondary phloem), and (3) secondary phloem adjacent

130 to the cambium (conducting secondary phloem) (Fig. 2B). All tissue regions measured 131 approximately $500 \times 2000 \mu \mathrm{m}$ (radial $\times$ tangential dimension). The total cross-sectional area 132 dissected from the 10 cross-sections per phloem cube was approximately $400000 \mu \mathrm{m}^{2}$ for 133 individual cell types and $3000000 \mu \mathrm{m}^{2}$ for tissue regions. When different cell types and tissue 134 regions were micro-dissected from the same cross-section, dissection of one was always 135 completed before starting the next to avoid cross-contamination.

\section{RNA extraction and boosting}

138 RNA was extracted independently from each tissue region and cell type, following the protocol

139 for the RNAqueous-Micro RNA Kit (Ambion Inc, Austin, TX, USA). Briefly, tissues and cells 140 were collected in RNA lysis buffer. Prior to cell lysis at $42{ }^{\circ} \mathrm{C}$, buffer was added to give a total 141 volume of $100 \mu$ lysate for a silica column-based purification with elution of total RNA, using 12 $142 \mu$ l elution buffer heated to $95^{\circ} \mathrm{C}$. DNase treatment was performed following the manufacturer's 
143 protocol. Due to differences in mRNA yield between tissue regions (consisting of a mixture of

144 different cell types) and pools of single cells, RNA extracts from single cells were boosted using

145 the MessageBOOSTER cDNA Synthesis Kit for qPCR (Epicentre Biotechnologies, Madison, WI,

146 USA) to obtain sufficient quantities of cDNA for qRT-PCR analyses (Yakovlev et al., 2006).

148 Quantitative Real Time RT-PCR (qRT-PCR) analysis

149 In order to identify tissue- and cell type-specific molecular defense responses, we analyzed the 150 expression of several transcripts using quantitative real-time reverse transcription PCR (qRT151 PCR). The qRT-PCR reactions were performed in single-plex conditions in a 96-well plate sealed 152 with a plastic film, using a 7500 Real Time PCR System (Applied Biosystems, Foster City, CA, 153 USA) with a reaction mixture consisting of $1 \times$ SYBR Green PCR Master Mix (Applied 154 Biosystems, Warrington, UK), $120 \mathrm{nM}$ of each primer, and $5 \mu \mathrm{l}$ of cDNA. The PCR program was 1552 minutes at $50{ }^{\circ} \mathrm{C}, 10$ minutes at $95^{\circ} \mathrm{C}$ followed by 40 cycles of $15 \mathrm{~s}$ at $95{ }^{\circ} \mathrm{C}$ and $1 \mathrm{~min}$ at 60 $156{ }^{\circ} \mathrm{C}$

157 Absolute transcript quantification was performed using the 7500-system's SDS software 158 (Applied Biosystems, Foster City, CA, USA). The expression level of each target gene was normalized to the transcript level of the endogenous control actin (PaAct), both in infected and control samples. PaAct was used as the endogenous control reference since it has been shown to

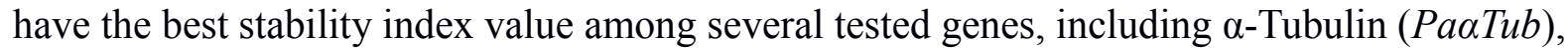
glyceraldehyde-3-phosphate dehydrogenase $(\mathrm{PaGAPDH})$ and polyubiquitin $(\mathrm{PaUbq})$ (Yakovlev et al., 2006). Samples with low RNA yield (cycle threshold (Ct) value for actin above 35) were excluded from candidate gene transcript. The targeted gene transcript levels were profiled by gene specific primers described and verified in previous studies (Table 1).

\section{RESULTS}

170 No hyphae were observed in phloem 5 or $10 \mathrm{~mm}$ above the inoculation site 3 days after

171 inoculation and the tissue showed no anatomical changes compared to control tissue (Figs. 1A

172 and 1B). However, by day 7 and 14, C. polonica hyphae had extended 5 to $10 \mathrm{~mm}$ away from the

173 inoculation site, mostly growing within the lumen of ray cells and PP cells (Figs. 1C and 1D). By

174 day 35, hyphae were observed growing into and through large phenolic aggregations present 175 within these cells. 


\section{Identification of cells for laser micro-dissection}

178 Cryo-sectioned tissues showed cell morphology that was in an adequate state of preservation.

179 Before laser micro-dissection we were able to identify ray and PP cells based on morphological

180 features such as cell shape, orientation, cellular tissue architecture and cytoplasmic content. In

181 phloem cross-sections PP cells can be identified by their rounded shape, their occurrence in

182 multiple axial rows separated by 5-7 layers of empty sieve cells, and the presence of polyphenolic

183 globules and starch grains in their cell lumen. The ray parenchyma cells have a characteristic

184 radially elongated shape, form chain-like rows radiating through the bark and extending into the

185 xylem, and contain polyphenolic aggregates and starch grains that appear irregularly in small

186 amounts (Figs. 2B and 2C).

\section{Transcript levels in control material}

189 TIF was constitutively expressed at levels similar to our endogenous reference actin in both 190 whole tissue regions and individual cell types. Transcript levels of $C H I 4, P A L, S P I$ and $P X 3$, 191 were detectable in some un-inoculated tissue, but at a low to very low level (Table 2). This was 192 also the case for DXP, LAS and ACS (data not shown). The low constitutive expression level of

193 these genes was further confirmed in additional control samples that were collected from two un194 inoculated ramets of clone 471 in July 2010 (see supplement). The average fold-difference in 195 transcript levels between the 2003 and 2010 controls was $<0.25$ for tissue types and 0.43 for cell 196 types (average for all three tissue/cell types and all the eight target gene transcripts studied)

\section{Transcript levels in different phloem regions of infected bark}

199 The analysed phloem tissue regions consisted of several cell types including living parenchyma

200 cells (ray and PP cells), dead sieve cells, and cambium parenchyma. Three days after inoculation,

$201 C H I 4, P A L$ and $P X 3$ showed increased transcript levels in all three tissue regions examined

202 (primary phloem near the bark surface, non-conducting and conducting secondary phloem), but

203 generally less so in the primary phloem (Table 2). Upregulation level of CHI4,PAL and PX3

204 showed some ramet-specific variation but commonly dropped from 5 to $10 \mathrm{~mm}$ above the

205 inoculation site. The terpene related genes DXPS and LAS (data not shown), the ethylene

206 biosynthesis related ACS (data not shown), as well as SPI3 and TIF showed no consistent

207 induction in phloem 3 days after inoculation, neither close to $(5 \mathrm{~mm})$ or further away $(10 \mathrm{~mm})$

208 from the inoculation site (Table 2). 


\section{Transcripts levels in different cell types of infected bark}

211 As with tissues, also the laser micro-dissected cell types displayed some ramet-specific variation

212 but with clear induction of CHI4, PAL and PX3 transcripts 3 days after inoculation. Maximum

213 transcript levels of these genes were generally recorded in the area adjacent to the site of

214 inoculation (Table 2). The highest transcript levels of CHI4, PAL and PX3 were usually observed

215 in ray cells. Regarding PAL, the three targeted cell types showed a relatively similar induction

216 level. Cambium displayed clearly lower induction of CHI4 than ray and PP cells, whereas PP

217 cells showed the lowest induction level of PX3. No clear induction compared to cells from un-

218 inoculated control tissue was observed for DXPS, LAS, ACS (data not shown), SPI1 or the

219 constitutively expressed TIF (Table 2).

220

221

\section{DISCUSSION}

222

223

This study demonstrated the usefulness of the laser micro-dissection technique coupled with qRTPCR for deciphering cell type-specific induced defense responses in conifer phloem. The LMD procedure followed in this paper did not include chemical fixation and histological stains, but still allowed identification of the various cell types based on morphological characteristics. Conventional cytological analyses rely on tissue treatment with fixatives and stains, which are likely to impact subsequent extraction and quality of RNA. When the constitutive bark defense of conifers is compromised, induced host responses are launched in the neighboring tissue in order to kill or compartmentalize the invader. We focused on short-term molecular defense responses occuring within 3 days after fungal inoculation in tissues that locate 5 to $10 \mathrm{~mm}$ away from the site of bark wounding and infection. At this early stage of infection these adjacent tissues are not visibly damaged and compartmentalization associated anatomical and chemical changes have not yet been completed. The use of phloem cross-sections enabled us to evaluate the fungal colonization status of the whole phloem region in a single cut extending from the outer bark into the cambium, and also allowed dissection of different tissue regions and cell types from the same section. The tangential sectioning procedure used by Abbott et al. (2010) to study resin ducts would have required a larger number of sections to be cut in our case.

In comparison to infected bark, the transcripts of $C H I 4, P A L$, and $P X 3$ were either absent or at a very low level in all analyzed tissue and cell types of control bark (Table 2). The contrasting 
241 transcript levels of these genes between infected and control bark are consistent with a role in 242 induced bark defense.

243 The class IV chitinase CHI4 was up-regulated close to the inoculation site particularly in ray 244 and PP cells. CHI4 has been demonstrated to have antifungal effects (Ubhayasekera et al., 2009) 245 and has been indicated to mediate programmed cell death (PCD) during embryogenesis in 246 Norway spruce (Wiweger et al., 2003). Mediation of PCD by CHI4 presumably occurs through 247 action on endogenous arabinogalactan proteins or lipo-chitooligosaccharides (Wiweger et al., 248 2003), conceptually releasing oligosaccharides with signaling properties (Fossdal et al., 2006). 249 CHI4 was much more highly induced in ray and PP cells close to the inoculation site than further 250 away. This pattern may be caused by PCD that precedes formation of a ligno-suberized boundary zone (LSZ), a process in which PP cells are instrumental (Franceschi et al., 1998; 2000; 2005).

Phenylalanine ammonia lyase $(P A L)$, the basal enzyme in the phenylpropanoid pathway, is upstream of both lignin and polyphenol synthesis. $P A L$ was also up-regulated in both ray and PP cells, although to much lower levels than $C H I 4$. In all tissues $P A L$ was most strongly up-regulated close to the inoculation site and this may be due to increased monolignol production and lignification of the LSZ that is forming to contain the infection. However, clarification of downstream events in cells with $P A L$ induction will require transcript profiling of genes specific to lignin biosynthesis and phytoalexin formation. The phenolic content of PP cells can be rapidly activated and modified following infection, since the PP cells have ample energy supplies in the form of stored starch and lipids (e.g. Krekling et al., 2000). Activation or swelling of PP cells following infection results in a four-fold increase in their volume and changes in the appearance of their phenolic content (Fossdal et al., 2003; 2006; Nagy et al., 2005; Yaqoob et al., 2012). The swelling leads to extensive compression of the surrounding sieve cells, transforming the induced phloem into dense blocks of cell walls separated by layers of swollen PP cells. This combined cell wall/PP cell barrier appears to be reinforced by phenolics that are released from the induced PP cells and deposited in the surrounding sieve cell walls (Franceschi et al., 2000). In Sitka spruce cell-wall bound phenols (but not lignin) have been shown to increase rapidly in the bark $10 \mathrm{~mm}$ from inoculation sites following inoculation with $H$. annosum (Deflorio et al., 2011).

Up-regulation of the peroxidase $P X 3$ was very pronounced in the cambium and in ray cells close to the site of wounding and inoculation. Peroxidases appear to play a role in cell wall formation by providing the radical-generating capability for coupling individual phenolic

272 monomers into complex lignin polymers (e.g. Ralph et al., 2004). In Norway spruce $P X 3$ is 273 believed to be involved in oxidative processes leading to increased cell wall lignification 
274 (Koutaniemi et al., 2007). This is supported by earlier experiments showing increased levels of

275 lignification in the bark following wounding and inoculation with fungus (Fossdal et al., 2001;

276 Deflorio et al., 2011). Likewise, Koutaniemi et al. (2007) found highly induced levels of $P X 3$ in

277 compression wood and bark of Norway spruce trees inoculated with the decay fungus

278 Heterobasidion parviporum but not in normal developing xylem. The low transcript levels of

$279 P X 3$ in PP cells are noteworthy and might be due to the role of phenolics released from PP cells

280 in reinforcing the cell walls of the surrounding sieve cells An alternative possibility is that a

281 major part of the phenolics synthesized by PP cells upon bark compromise are soluble rather than

282 cell-wall bound.The translation initiation factor TIF was used as an endogenous qRT-PCR

283 reference transcript in a related study of bark defenses in white spruce by Abbott et al. (2010).

284 This fits well with the constitutive expression levels observed in our study, were TIF had similar

285 expression levels as our endogenous reference actin. The expression level of genes involved in

286 terpenoid resin synthesis ( $D X P S, L A S, A C S)$ showed no clear induction in our study. For example

$287 L A S$ (levopimaradiene abietadiene synthase), a major enzyme in diterpene biosynthesis, was

288 almost undetectable in our samples. This suggests that our targeted cell types are not involved in

289 resin biosynthesis and accords well with earlier findings in white spruce and Sitka spruce, where

290 LAS activity was found to be localized to cortical resin ducts and to be absent from other tissues

291 (Abbott et al., 2010; Zulak et al., 2010; Zulak \& Bohlmann, 2010).

292 The use of a single Norway spruce genotype in this study brings into question the general

293 applicability of our results. Our findings are strengthened by the consistent differences observed

294 between control and infected bark, between tissue and cell types, with distance from the

295 inoculation site, and between different gene transcripts. Further, our data are consistent with

296 previous studies describing the regulation of these gene transcripts in bulk tissues of other

297 Norway spruce genotypes following wounding and pathogen inoculation. For example, $\mathrm{PaCHI}$

298 was the most highly up-regulated transcript in this study (Table 2), as has been shown in

299 numerous earlier studies (Fossdal et al., 2006; 2007; 2012; Yaqoob et al., 2012). Our previous

300 study suggested that resistant and susceptible Norway spruce clones differ in the rapidity of

301 PaCHI4-related signal perception or transduction in the challenged inner bark (Hietala et al.,

302 2004); it remains to be examined whether resistant and susceptible clones differ in the rate and

303 level of reprogramming of all cell types upon wounding/pathogen challenge. 
306 Laser micro-dissection greatly increases the resolution of mRNA analyses by allowing gene expression profiling of specific cell types. We applied this method to analyze gene expression in the key cell types involved in defense of Norway spruce phloem, namely polyphenolic parenchyma (PP) and ray parenchyma cells. Laser micro-dissection is particularly applicable in combination with qRT-PCR when preserving chemicals are avoided. While the low number of replicates limits the biological conclusions that can be drawn from this study, we have demonstrated that the induced expression profiles of particularly $C H I 4$ and $P X 3$ differed between vascular cambium, PP cells and ray parenchyma, suggesting that these cell types have overlapping but not fully redundant roles in active defense of Norway spruce phloem.

\section{REFERENCES}

Abbott E, Hall D, Hamberger B, Bohlmann J. 2010. Laser microdissection of conifer stem tissues: isolation and analysis of high quality RNA, terpene synthase enzyme activity and terpenoid metabolites from resin ducts and cambial zone tissue of white spruce (Picea glauca). BMC Plant Biology 10:106.

Christiansen E, Bakke A. 1988. The spruce bark beetle of Eurasia. In: Berryman AA, ed. Dynamics of forest insect populations. New York: Plenum Publisher Corporation, 479-503.

Deflorio G, Horgan G, Woodward S, Fossdal CG. 2011. Gene expression profiles, phenolics and lignin of Sitka spruce bark and sapwood before and after wounding and inoculation with Heterobasidion annosum. Physiological and Molecular Plant Pathology 75:180-187.

del Cerro M, Cogen J, del Cerro C. 1980. Stevenel's blue, an excellent stain for optical microscopical study of plastic embedded tissues. Microscopica Acta 83:117-121.

Fossdal CG, Hietala AM, Kvaalen H, Solheim H. 2006. Changes in host chitinase isoforms in relation to wounding and colonization by Heterobasidion annosum: early and strong defense response in 33-year-old resistant Norway spruce clone. Tree Physiology 26:169-177.

Fossdal CG, Nagy NE, Johnsen O, Dalen LS. 2007. Local and systemic stress responses in Norway spruce: Similarities in gene expression between a compatible pathogen interaction and drought stress. Physiological and Molecular Plant Pathology 70:161-173.

Fossdal CG, Nagy NE, Sharma P, Lönneborg A. 2003. The putative gymnosperm plant defensin polypeptide (SPI1) accumulates after seed germination, is not readily released, and 
the SPI1 levels are reduced in Pythium dimorphum-infected spruce roots. Plant Molecular Biology 52: 291-302.

Fossdal CG, Sharma P, Lönneborg A. 2001. Isolation of the first putative peroxidase cDNA from a conifer and the local and systemic accumulation of related proteins upon pathogen infection. Plant Molecular Biology 47:423-435.

Fossdal CG, Yaqoob N, Krokene P, Kvaalen H, Solheim H, Yakovlev IA. 2012. Local and systemic changes in expression of resistance genes, nb-lrr genes and their putative microRNAs in Norway spruce after wounding and inoculation with the pathogen Ceratocystis polonica. BMC Plant Biology 12:105.

Hietala AM, Kvaalen H, Schmidt A, Jøhnk N, Solheim H, Fossdal CG. 2004. Temporal and spatial profiles of chitinase expression by Norway spruce in response to bark colonization by Heterobasidion annosum. Applied and Environmental Microbiology 70: 3948-3953.

Franceschi VR, Krekling T, Berryman AA, Christiansen E. 1998. Specialized phloem parenchyma cells in Norway spruce (Pinaceae) bark are an important site of defense reactions. American Journal of Botany 85:601-615.

Franceschi VR, Krokene P, Christiansen E, Krekling T. 2005. Anatomical and chemical defenses of conifer bark against bark beetles and other pests. New Phytologist 167:353-375.

Franceschi VR, Krokene P, Krekling T, Christiansen E. 2000. Phloem parenchyma cells are involved in local and distant defense responses to fungal inoculation or bark-beetle attack in

Koutaniemi S, Warinowski T, Karkonen A, Alatalo E, Fossdal CG, Saranpaa P, Laakso T, Fagerstedt KV, Simola LK, Paulin L, Rudd S, Teeri TH. 2007. Expression profiling of the lignin biosynthetic pathway in Norway spruce using EST sequencing and real-time RT-PCR. Plant Molecular Biology 65:311-328.

Krekling T, Franceschi VR, Berryman AA, Christiansen E. 2000. The structure and development of polyphenolic parenchyma cells in Norway spruce (Picea abies) bark. Flora 195:354-369.

Krokene P, Nagy NE, Krekling T. 2008. Traumatic Resin Ducts and Polyphenolic Parenchyma Cells in Conifers. In: Schaller A, ed. Induced plant resistance to herbivory. Springer Science+Business Media B.V., 147-169.

Li S-H, Nagy NE, Hammerbacher A, Krokene P, Niu X-M, Gershenzon J, Schneider B. 2012. Localization of phenolics in phloem parenchyma cells of Norway spruce (Picea abies). ChemBioChem 13:2707-2713. 
Li S-H, Schneider B, Gershenzon J. 2007. Microchemical analysis of laser-microdissected stone cells of Norway spruce by cryogenic nuclear magnetic resonance spectroscopy. Planta 225:771-779.

Luchi N, Capretti P, Fossdal CG, Pazzagli M, Pinzani P. 2012. Laser microdissection on Norway spruce bark tissue: A suitable protocol for subsequent real-time reverse transcriptionpolymerase chain reaction (RT-PCR) analysis. Plant Biosystems 146:92-98.

Ubhayasekera W, Rawat R, Ho S, Wiweger M, Von Arnold S, Chye M-L, Mowbray S. 2009.

Nagy NE, Fossdal CG, Krokene P, Krekling T, Lönneborg A, Solheim S. 2004. Induced responses to pathogen infection in Norway spruce phloem: changes in polyphenolic parenchyma cells, chalcone synthase transcript levels and peroxidase activity. Tree Physiology 24:505-515.

Nagy NE, Franceschi VR, Kvaalen H, Solheim H. 2005. Callus cultures and bark from Norway spruce clones show similar cellular features and relative resistance to fungal pathogens. Trees - Structure and Function 19:694-702.

Nagy NE, Franceschi VR, Solheim H, Krekling T, Christiansen E. 2000. Wound-induced traumatic resin duct development in stems of Norway spruce (Pinaceae): Anatomy and cytochemical traits. American Journal of Botany 87:302-313.

\section{Ralph J, Bunzel M, Marita JM, Hatfield RD, Lu F, Kim H, Schatz PF, Grabber JH,} Steinhart H. 2004. Peroxidase-dependent cross-linking reactions of $p$-hydroxycinnamates in plant cell walls. Phytochemistry Reviews 3:79-96.

$$
\text { The first crystal structures of a family } 19 \text { class IV chitinase: The enzyme from Norway spruce. }
$$
Plant Molecular Biology 71:277-289.

Wermelinger B, Seifert M. 1999. Temperature-dependent reproduction of the spruce bark beetle Ips typographus, and analysis of the potential population growth. Ecological Entomology 24:103-110.

Wiweger M, Farbos I, Ingouff M, Lagercrantz U, Von Arnold S. 2003. Expression of Chia4Pa chitinase genes during somatic and zygotic embryo development in Norway spruce (Picea abies): similarities and differences between gymnosperm and angiosperm class IV chitinases. Journal of Experimental Botany 54:2691-2699.

Yakovlev IA, Fossdal CG, Johnsen Ø, Junttila O, Skrøppa T. 2006. Analysis of gene expression during bud burst initiation in Norway spruce via ESTs from subtracted cDNA libraries. Tree Genetics and Genomes 2:39-52. 
402 Yaqoob N, Yakovlev IA, Krokene P, Kvaalen H, Solheim H, Fossdal CG. 2012. Defence-

403 related gene expression in bark and sapwood of Norway spruce in response to Heterobasidion

404 parviporum and methyl jasmonate. Physiological and Molecular Plant Pathology 77:10-16.

405 Zulak KG, Bohlmann J. 2010. Terpenoid biosynthesis and specialized vascular cells of conifer

406 defense. Journal of Integrative Plant Biology 52:86-97.

407 Zulak KG, Dullat HK, Keeling CI, Lippert D, Bohlmann J. 2010. Immunofluorescence

408 localization of levopimaradiene/abietadiene synthase in methyl jasmonate treated stems of

409 Sitka spruce (Picea sitchensis) shows activation of diterpenoid biosynthesis in cortical and

410 developing traumatic resin ducts. Phytochemistry 71:1695-1699. 


\section{Figure 1}

\section{High resolution characteristics of Norway spruce phloem 0-14 days after inoculation with the necrotroph Ceratocystis polonica.}

(A) Polyphenolic parenchyma cells (PPC) and ray cells (RC) in control tissue with turquois stained phenolics and unstained starch grains. (B) PPC and RC 3 days after infection, the time point at which cells and tissues were collected for laser micro-dissection and real-time qRT-PCR analysis. (C, D) Arrows indicate hyphae of C. polonica inside cells 7 and 14 days after inoculation. Bars $=50 \mu \mathrm{m}$. All cross-sections ( $1 \mu \mathrm{m}$ thick) represent conducting secondary phloem sampled $5 \mathrm{~mm}$ above the inoculation site and embedded in acrylic resin. 


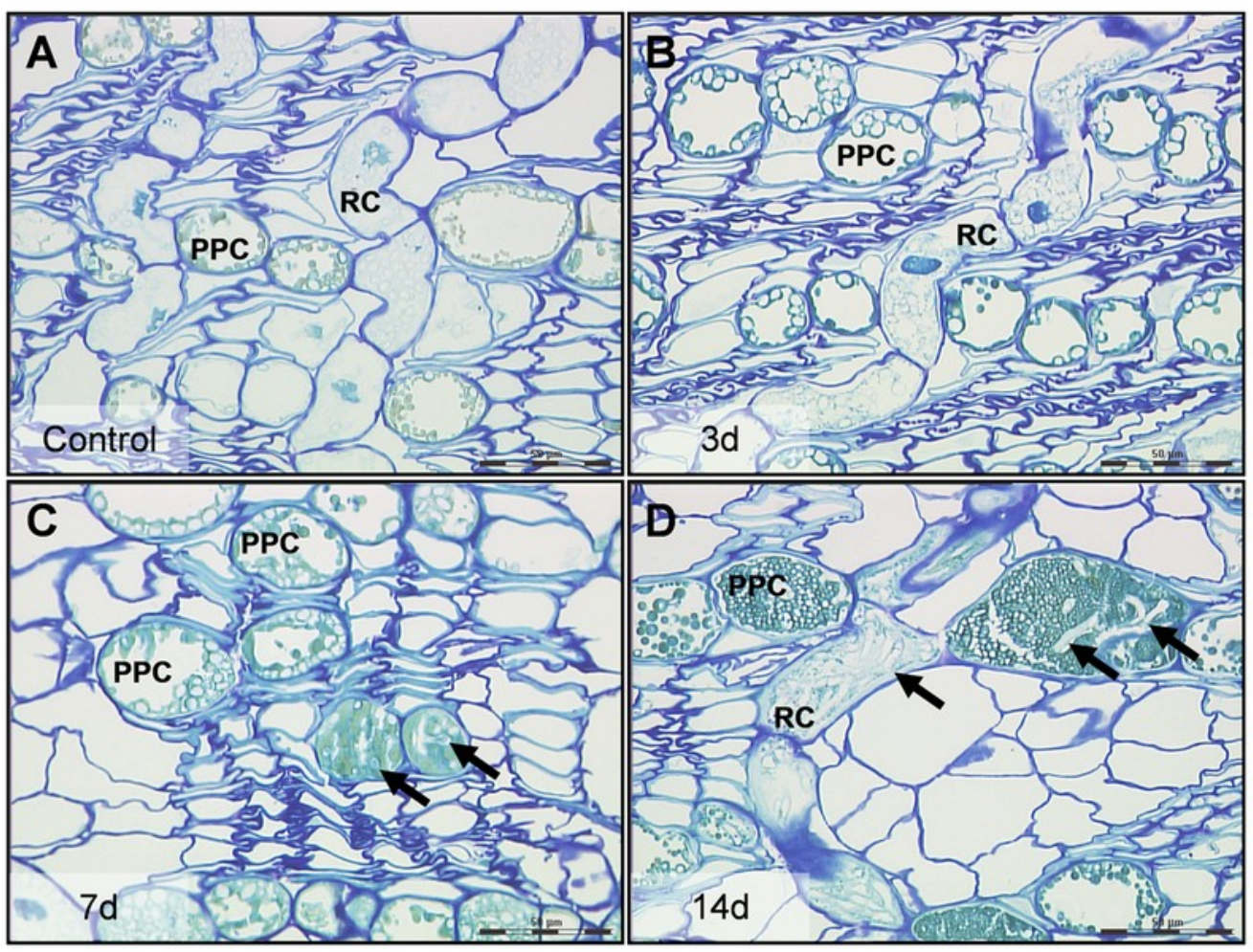




\section{Figure 2}

\section{Tissue regions and cell types in Norway spruce phloem selected for laser micro- dissection.}

(A) Schematic outline of a bark sample showing the inoculation site and positions were tissue cross-sections were taken. (B) Overview of primary and secondary phloem in cross-section from the periderm to the cambium, with dissected regions and cell types dissected. 1: a 500 $\mu \mathrm{m}$ wide region of non-conducting primary phloem tissue adjacent to the outer bark. 2: a 500 $\mu \mathrm{m}$ wide region of non-conducting secondary phloem $1000 \mu \mathrm{m}$ away from region 1. 3: a 500 $\mu \mathrm{m}$ wide region of conducting secondary phloem adjacent to the periderm. 4: cambium parenchyma cells. (C) Cross-section of cryo-embedded tissue showing polyphenolic parenchyma cells (PPC) and ray parenchyma cells $(\mathrm{RC})$ in the secondary phloem selected for laser micro-dissection. 

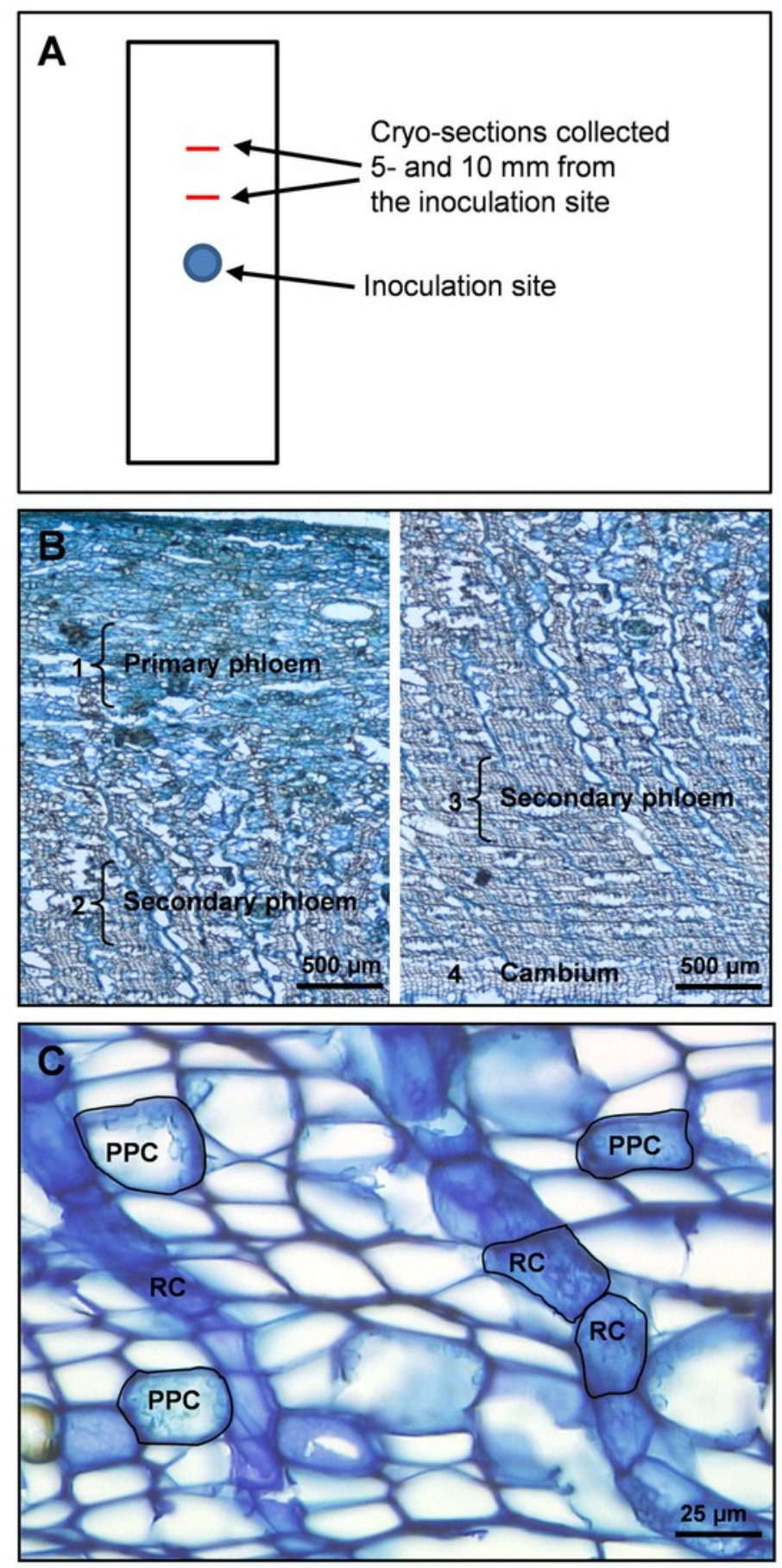


\section{Table 1 (on next page)}

Primer sequences used for real time qRT-PCR analysis of micro-dissected Norway spruce phloem tissues and cells. 


\begin{tabular}{|c|c|c|c|}
\hline Gene & Gene name and reference & $\begin{array}{l}\text { GenBank } \\
\text { Accs.* }\end{array}$ & Primer sequences (forward/reverse, 5'-3') \\
\hline PaAct & Actin (Yakovlev et al. 2006) & AAF03692 & TGAGCTCCCTGATGGGCAGGTGA/TGGATACCAGCAGCTTCCATCCC \\
\hline $\mathrm{PaCHI} 4$ & $\begin{array}{l}\text { Chitinase (Fossdal et al. } \\
\text { 2007, Yakoob et al. 2012) }\end{array}$ & AY544780 & $\begin{array}{l}\text { AAT } \\
\text { GCGAGGGCAAGGGATTCTAC/GTGGTGCCAAATCCAGAAA }\end{array}$ \\
\hline SPI1 & $\begin{array}{l}\text { Defensin (Fossdal et al. } \\
\text { 2007) }\end{array}$ & X91487 & $\begin{array}{l}\text { TGTGGCCAACAGAAAGTGCTA/CCAGTGAAGATCACAGTAGTAGGAT } \\
\text { TAGG }\end{array}$ \\
\hline PaPX3 & $\begin{array}{l}\text { Peroxidase (Koutaniemi et } \\
\text { al. 2007; Yaqoob et al. 2012) }\end{array}$ & AJ566203 & ATGGTGGCGCTGTCAATTC/TGCTGTAGAACGTCCAAGAAAGAC \\
\hline PAL & $\begin{array}{l}\text { Phenylalanine } \\
\text { ammonialyase (Deflorio et } \\
\text { al. 2011) }\end{array}$ & AY639588 & CAGCCCTCTGCCCAACAG/AGCTGGGTTCTCACGAATTCA \\
\hline DXPS & $\begin{array}{l}\text { 1-deoxyxyulose-5- } \\
\text { phosphate synthase (Abbott } \\
\text { et al. 2010) }\end{array}$ & EF688333 & $\begin{array}{l}\text { AGAAACTCCCTGTGAGATTTGCCCTT/CAACAGTAACTGATATGCCCT } \\
\text { GCTGAG }\end{array}$ \\
\hline LAS & $\begin{array}{l}\text { Levopimaradiene diterpene } \\
\text { synthase (Abbott et al. 2010) }\end{array}$ & AY473621 & $\begin{array}{l}\text { GGACGATCTCAAGTTGTTTTCCGATTC/TGAGAACCACTGTTCCCAG } \\
\text { CGC }\end{array}$ \\
\hline ACS & $\begin{array}{l}\text { 1-aminocyclopropane-1- } \\
\text { carboxylate synthase }\end{array}$ & BT108790 & $\begin{array}{l}\text { CAAGCAGAATCCCTATGATGCCGAAA/TCTGGATGAGACTTGAGCCA } \\
\text { АССTTC }\end{array}$ \\
\hline TIF & $\begin{array}{l}\text { (Yaqoob et al. 2012) } \\
\text { Translation initiation factor } \\
\text { (Abbott et al. 2010) }\end{array}$ & AY961930 & CATCCGCAAGAACGGCTACATC/GTAACATGAGGGACATCGCAG \\
\hline
\end{tabular}

*References denote related studies were these gene transcripts were used. 


\section{Table 2 (on next page)}

Expression profiles of five genes in different tissue regions and cell types of Norway spruce phloem, after inoculation with Ceratocystis polonica and in control.

Gene expression was determined in sections taken 5 and $10 \mathrm{~mm}$ above the inoculation site in ramet $A$ and $B$ of clone 471 . Data are presented as relative transcript abundance normalized to actin expression. Dash (-), indicates that the sample was not subjected to target gene profiling due to low RNA yield (cycle threshold value for actin above 35). 


\begin{tabular}{|c|c|c|c|c|c|c|c|}
\hline \multirow[b]{2}{*}{ Gene } & \multirow[b]{2}{*}{ Tissue and cells } & \multicolumn{4}{|c|}{ Infected } & \multicolumn{2}{|c|}{ Control } \\
\hline & & Ramet A $5 \mathrm{~mm} \mathrm{d3}$ & Ramet A $10 \mathrm{~mm}$ d3 & Ramet B 5mm d3 & Ramet B $10 \mathrm{~mm}$ d3 & Ramet A site1 d35 & Ramet A site2 d35 \\
\hline \multirow[t]{6}{*}{$\begin{array}{c}\mathrm{CHI} 4 \\
\mathrm{C}\end{array}$} & Primary phloem & 3.03 & - & 0.86 & 1.38 & 0.00 & 0.01 \\
\hline & Sec. phloem conducting & 19.52 & 1.32 & 6.78 & 1.74 & 0.00 & 0.04 \\
\hline & Sec. phloem non-conducting & 49.84 & 1.76 & 2.45 & 0.60 & 0.00 & 0.00 \\
\hline & Cambium & 5.21 & 1.03 & 0.41 & - & 0.20 & 0.02 \\
\hline & Ray cells & 51.66 & 3.87 & 4.36 & 0.49 & 0.00 & 0.00 \\
\hline & PP cells & 29.79 & 3.64 & 2.35 & 0.30 & 0.00 & 3.71 \\
\hline \multirow[t]{6}{*}{ PAL } & Primary phloem & 3.72 & - & 2.23 & 1.68 & 0.02 & 0.05 \\
\hline & Sec. phloem conducting & 2.44 & 1.89 & 4.34 & 0.81 & 0.14 & 0.14 \\
\hline & Sec. phloem non-conducting & 7.42 & 2.07 & 3.20 & 0.87 & 0.03 & 0.02 \\
\hline & Cambium & 6.09 & 1.09 & 2.62 & - & 0.08 & 0.05 \\
\hline & Ray cells & 8.21 & 4.85 & 4.27 & 1.89 & 0.00 & 0.00 \\
\hline & PP cells & 3.65 & 6.42 & 1.60 & 2.33 & 0.00 & 0.38 \\
\hline \multirow[t]{6}{*}{ SPI1 } & Primary phloem & 0.81 & - & 0.00 & 0.00 & 0.00 & 0.00 \\
\hline & Sec. phloem conducting & 0.37 & 2.54 & 0.00 & 0.80 & 1.32 & 0.42 \\
\hline & Sec. phloem non-conducting & 0.41 & 2.18 & 0.53 & 0.11 & 2.48 & 0.31 \\
\hline & Cambium & 0.36 & 4.31 & 4.13 & - & 0.00 & 0.00 \\
\hline & Ray cells & 3.96 & 5.74 & 2.29 & 5.35 & 0.00 & 0.00 \\
\hline & PP cells & 0.46 & 0.47 & 0.34 & 1.34 & 0.00 & 0.00 \\
\hline \multirow[t]{6}{*}{ PX3 } & Primary phloem & 0.07 & - & 0.10 & 0.05 & 0.00 & 0.01 \\
\hline & Sec. phloem conducting & 0.24 & 0.12 & 1.22 & 0.83 & 0.00 & 0.00 \\
\hline & Sec. phloem non-conducting & 0.33 & 0.39 & 0.53 & 0.16 & 0.00 & 0.00 \\
\hline & Cambium & 0.37 & 0.43 & 13.73 & - & 0.94 & 0.00 \\
\hline & Ray cells & 1.90 & 0.38 & 11.07 & 1.03 & 0.00 & 0.00 \\
\hline & PP cells & 0.06 & 0.00 & 0.18 & 0.11 & 0.00 & 0.00 \\
\hline \multirow[t]{6}{*}{ TIF } & Primary phloem & 1.59 & - & 0.90 & 0.71 & 0.76 & 0.48 \\
\hline & Sec. phloem conducting & 0.99 & 1.17 & 0.81 & 0.59 & 3.11 & 0.70 \\
\hline & Sec. phloem non-conducting & 2.18 & 1.32 & 0.68 & 0.62 & 0.94 & 0.60 \\
\hline & Cambium & 1.28 & 1.10 & 2.59 & - & 2.84 & 1.13 \\
\hline & Ray cells & 3.28 & 1.75 & 2.65 & 1.82 & 0.69 & 1.03 \\
\hline & PP cells & 2.20 & 0.83 & 0.67 & 1.55 & 0.00 & 0.00 \\
\hline
\end{tabular}

Ramet $=$ trees of Norway spruce clone number $471 ; \mathrm{mm}=$ distance from inoculation site; $d=$ day 